January 2003 • NREL/CP-550-33209

\title{
A Parabolic Trough Solar Power Plant Simulation Model
}

\section{Preprint}

\section{H. Price}

To be presented at the ISES 2003:

International Solar Energy Conference

Hawaii Island, Hawaii

March 16-18, 2003

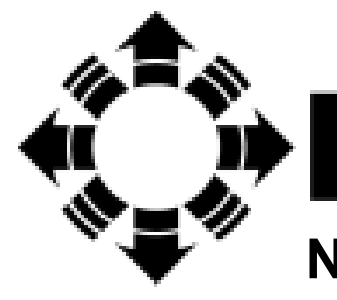

National Renewable Energy Laboratory

1617 Cole Boulevard

Golden, Colorado 80401-3393

NREL is a U.S. Department of Energy Laboratory

Operated by Midwest Research Institute • Battelle • Bechtel

Contract No. DE-AC36-99-G010337 


\section{NOTICE}

The submitted manuscript has been offered by an employee of the Midwest Research Institute (MRI), a contractor of the US Government under Contract No. DE-AC36-99G010337. Accordingly, the US Government and MRI retain a nonexclusive royalty-free license to publish or reproduce the published form of this contribution, or allow others to do so, for US Government purposes.

This report was prepared as an account of work sponsored by an agency of the United States government. Neither the United States government nor any agency thereof, nor any of their employees, makes any warranty, express or implied, or assumes any legal liability or responsibility for the accuracy, completeness, or usefulness of any information, apparatus, product, or process disclosed, or represents that its use would not infringe privately owned rights. Reference herein to any specific commercial product, process, or service by trade name, trademark, manufacturer, or otherwise does not necessarily constitute or imply its endorsement, recommendation, or favoring by the United States government or any agency thereof. The views and opinions of authors expressed herein do not necessarily state or reflect those of the United States government or any agency thereof.

Available electronically at http://www.osti.gov/bridge

Available for a processing fee to U.S. Department of Energy and its contractors, in paper, from:

U.S. Department of Energy

Office of Scientific and Technical Information

P.O. Box 62

Oak Ridge, TN 37831-0062

phone: 865.576.8401

fax: 865.576.5728

email: reports@adonis.osti.gov

Available for sale to the public, in paper, from:

U.S. Department of Commerce

National Technical Information Service

5285 Port Royal Road

Springfield, VA 22161

phone: 800.553 .6847

fax: 703.605.6900

email: orders@ntis.fedworld.gov

online ordering: http://www.ntis.gov/ordering.htm

Printed on paper containing at least $50 \%$ wastepaper, including $20 \%$ postconsumer waste 


\title{
A PARABOLIC TROUGH SOLAR POWER PLANT SIMULATION MODEL
}

\author{
Henry Price \\ National Renewable Energy Laboratory \\ 1617 Cole Blvd., Golden, Colorado, 80401 \\ henry_price@nrel.gov
}

\begin{abstract}
As interest for clean renewable electric power technologies grows, a number of parabolic trough power plants of various configurations are being considered for deployment around the globe. It is essential that plant designs be optimized for each specific application. The optimum design must consider the capital cost, operations and maintenance cost, annual generation, financial requirements, and time-of-use value of the power generated. Developers require the tools for evaluating tradeoffs between these various project elements. This paper provides an overview of a computer model that is being used by scientists and developers to evaluate the tradeoff between cost, performance, and economic parameters for parabolic trough solar power plant technologies. An example is included that shows how this model has been used for a thermal storage design optimization.
\end{abstract}

\section{INTRODUCTION}

The National Renewable Energy Laboratory ${ }^{1}$ (NREL) currently leads the research and develoment (R\&D) efforts on parabolic trough solar power technology within the U.S. Department of Energy's (DOE) Concentrating Solar Power (CSP) program. DOE supports the use of systems-driven analysis for evaluation of technologies and supporting $R \& D$ decisions. NREL has developed a parabolic trough simulation model that allows a detailed performance, cost, and economic assessment of design and technology variations. NREL uses this model to help direct $R \& D$ efforts in the parabolic trough program. This paper provides an overview of this model and presents an example of its use.

\footnotetext{
1 NREL is part of the SunLab collaboration with Sandia National Laboratories that jointly support the DOE CSP program.
}

\section{Performance Prediction}

Because solar plants rely on an intermittent fuel supplythe sun-it is necessary to model the plant's performance on an hourly (or finer resolution) basis to understand what the annual performance will be. A number of proprietary computer performance simulations have been developed for modeling the performance of parabolic trough plants. Luz International Limited developed an hourly simulation model that was used to help design the SEGS plants [1]. Flabeg Solar International (FSI, known as Pilkington Solar International and Flagsol before 1995) developed a performance simulation model to market parabolic trough plants and conduct design studies for clients [2]. KJC Operating Company (KJCOC), the operator of SEGS III-VII, has developed an hourly simulation code for assessing the performance of its plants [3]. This model is very specific to the 30-MWe plants at Kramer Junction and the needs of the operating company. As a result, it has limited capability for modeling different plant configurations. The German research laboratory Deutsches Zentrum fur Luft-und Raumfahrt e.V (DLR) has also developed a performance model for parabolic trough plants [4]. All of these codes are proprietary and are not generally available to the general public.

DLR and Sandia National Laboratories (SNL) have developed a special library for use with the TRNSYS thermal simulation software, to model parabolic trough solar power plants [5]. TRNSYS is a commercially available software package and is very suited for modeling complex systems, such as parabolic trough power plants. Unfortunately, TRNSYS requires very detailed input data to get results that accurately reflect expected plant performance. In addition, TRNSYS only calculates plant performance, thus economic trade-off studies must be iterated between TRNSYS and a separate economics model. 
NREL has developed a spreadsheet-based parabolic trough performance and economics model. The model has been developed in Microsoft Excel ${ }^{\circledR}$ spreadsheet program. The spreadsheet is used for data input and output. The model uses the Visual Basic for Applications language built into Excel for programming the hourly performance simulation. One of the advantages to this approach is that users do not require special software to use the program. A key feature of the NREL model is that capital cost, operation and maintenance (O\&M) cost, and financial calculations have been added directly to the model, which allows the plant design configurations to be more easily optimized. The model performs a time-step performance simulation based on plant design and a user-supplied operating strategy. The parabolic trough solar technology is modeled using the methodology developed by Stine and Harrigan [6]. The model is capable of modeling a Rankine-cycle parabolic trough plant, with or without thermal storage, and with or without fossil-fuel backup.

The NREL trough performance model has been validated by simulating the performance of the SEGS VI power plant and comparing the modeled output results with actual plant operating data. The closeness of such a comparison reflects the accuracy and applicability of the model. The validation presented here focuses on the solar portion of the plant and excludes days with fossil-fuel operation. We compared the actual and modeled daily gross solar electric production and parasitic electric consumption. KJC Operating Company (the operator of the SEGS III-VII plants) provided NREL with data for hourly direct normal insolation, daily total plant solar and fossil-fuel gross electric generation, and on-line and off-line parasitic electric consumption for the SEGS VI plant during 1999. The SEGS VI plant was selected because its solar field is composed of LS-2 parabolic trough collectors and its power cycle is the more advanced re-heat turbine, which uses the higher solar field operating temperature $735^{\circ} \mathrm{F}\left(391^{\circ} \mathrm{C}\right)$ that would likely be used at future plants.

The model input parameters were set up for the SEGS VI plant. Special considerations for SEGS VI include:

- Correcting for half-cermet and half-black chrome HCEs

- Accounting for actual solar field collector HCE (broken, lost vacuum, and selective coating damaged HCEs) and mirror (broken) status

- Accounting for actual mirror cleanliness

- Adjusting for actual solar field availability.

The following figures show the comparison between actual and modeled plant gross electric generation and between actual and modeled on-line parasitic loads versus gross generation. Figure 1 shows excellent agreement between the actual and projected gross solar electric generation; a number of days are marked as excluded days. These days were identified in the KJCOC data as days when there was some plant outage or other problems that resulted in less than full performance. It should

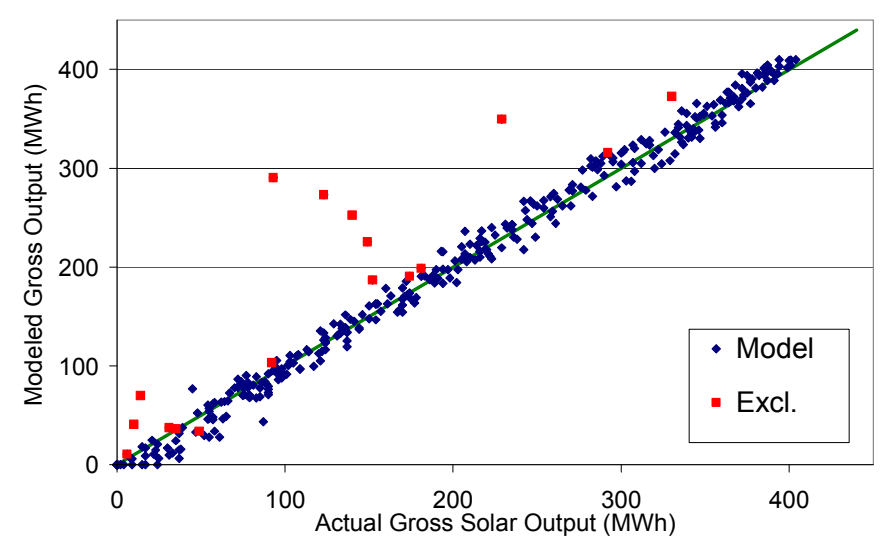

Figure 1 Daily modeled versus actual gross solar electric generation

be noted that this chart includes every day of the year. SEGS VI did not take an annual outage during 1999.

Table 1 shows how the model compared on a monthly and annual basis. The initial comparison includes all days and shows the model to be $1.5 \%$ high on an annual basis. The second comparison excludes the days that KJCOC identified as having availability issues (equipment or wind). In this case, the model is within $0.3 \%$ of the actual plant output. The final case depicts days with no fossil-fuel boiler operation. Here again, the predicted solar performance is within $2 \%$ of actual. Note that this comparison assumes $100 \%$ power plant availability. Some of the scatter in the results could be because KJCOC did not provide actual ambient temperature or wind data for 1999. The temperature and wind velocity data are used to estimate collector receiver thermal losses. The analysis used the Barstow typical meteorological year (TMY) wind and ambient temperature data that Luz used to model the SEGS plants. These are probably close on an annual basis, but will cause errors in individual days. In general, the comparison between actual and modeled gross solar electric generation appears to be excellent.

Figure 2 shows the comparison of the modeled and actual on-line electric parasitics for the SEGS VI plant during 1999. The figure plots the total daily parasitics while the plant is on line against the total daily gross generation. Only days with solar-only operation are shown because boiler operation would affect both on-line and off-line parasitics. There is good agreement between the modeled and actual parasitics. On an annual basis for days without fossil-fuel boiler operation, the modeled on-line solar parasitics were within $1 \%$ of actual. Note that there appears to be a significantly larger scatter for the actual solar parasitics than for the modeled parasitics. This may be the result of operator differences or caused by parasitic loads having a stronger dependence on ambient temperatures. Table 2 shows the monthly and annual comparisons. 
Table 1 Comparison of Actual versus Modeled Gross Solar Electric Output (SEGS VI 1999 Performance)

\begin{tabular}{|c|c|c|c|c|c|c|c|c|c|c|c|}
\hline \multirow[t]{2}{*}{ Month } & \multicolumn{3}{|c|}{ All Days } & \multicolumn{4}{|c|}{ Removing Excluded Days } & \multicolumn{4}{|c|}{ Removing Boiler Operation Days } \\
\hline & $\begin{array}{l}\text { Actual } \\
\text { MWh }\end{array}$ & $\begin{array}{l}\text { Model } \\
\text { MWh }\end{array}$ & $\begin{array}{l}\text { Model / } \\
\text { Actual }\end{array}$ & $\begin{array}{l}\text { No. of } \\
\text { Excluded } \\
\text { Days }\end{array}$ & $\begin{array}{l}\text { Actual } \\
\text { MWh }\end{array}$ & $\begin{array}{l}\text { Model } \\
\text { MWh }\end{array}$ & $\begin{array}{l}\text { Model / } \\
\text { Actual }\end{array}$ & $\begin{array}{l}\text { No. of } \\
\text { Solation } \\
\text { Days }\end{array}$ & $\begin{array}{l}\text { Actual } \\
\text { MWh }\end{array}$ & $\begin{array}{l}\text { Model } \\
\text { MWh }\end{array}$ & $\begin{array}{l}\text { Model / } \\
\text { Actual }\end{array}$ \\
\hline Jan & 1,853 & 1,649 & $89.0 \%$ & 3 & 1,781 & 1,564 & $87.8 \%$ & 0 & 0 & 0 & \\
\hline Feb & 3,080 & 2,950 & $95.8 \%$ & 0 & 3,080 & 2,950 & $95.8 \%$ & 0 & 0 & 0 & \\
\hline Mar & 4,968 & 4,813 & $96.9 \%$ & 1 & 4,919 & 4,779 & $97.1 \%$ & 31 & 4,968 & 4,813 & $96.9 \%$ \\
\hline Apr & 5,874 & 6,248 & $106.4 \%$ & 4 & 5,499 & 5,418 & $98.5 \%$ & 30 & 5,874 & 6,248 & $106.4 \%$ \\
\hline May & 9,209 & 9,264 & $100.6 \%$ & 3 & 8,636 & 8,471 & $98.1 \%$ & 30 & 8,827 & 8,869 & $100.5 \%$ \\
\hline Jun & 10,291 & 10,434 & $101.4 \%$ & 1 & 10,151 & 10,182 & $100.3 \%$ & 18 & 6,904 & 6,985 & $101.2 \%$ \\
\hline Jul & 9,311 & 9,592 & $103.0 \%$ & 1 & 9,137 & 9,401 & $102.9 \%$ & 18 & 6,309 & 6,505 & $103.1 \%$ \\
\hline Aug & 9,517 & 9,762 & $102.6 \%$ & 0 & 9,517 & 9,762 & $102.6 \%$ & 9 & 2,987 & 3,080 & $103.1 \%$ \\
\hline Sep & 7,218 & 7,488 & $103.7 \%$ & 1 & 6,926 & 7,172 & $103.6 \%$ & 9 & 2,304 & 2,358 & $102.3 \%$ \\
\hline Oct & 5,388 & 5,628 & $104.4 \%$ & 2 & 5,055 & 5,242 & $103.7 \%$ & 31 & 5,388 & 5,628 & $104.4 \%$ \\
\hline Nov & 2,538 & 2,500 & $98.5 \%$ & 1 & 2,446 & 2,397 & $98.0 \%$ & 30 & 2,538 & 2,500 & $98.5 \%$ \\
\hline Dec & 1,798 & 1,818 & $101.1 \%$ & 0 & 1,798 & 1,818 & $101.1 \%$ & 20 & 1,265 & 1,301 & $102.9 \%$ \\
\hline Total & 71,045 & 72,145 & $101.5 \%$ & 17 & 68,945 & 69,155 & $100.3 \%$ & 226 & 47,364 & 48,287 & $101.9 \%$ \\
\hline
\end{tabular}

Off-line parasitic loads were adjusted to match the parasitic loads for the SEGS VI plant. SEGS VI circulates the solar field HTF 24 hours per day to minimize thermal shocks to the trough receiver tubes and HTF pumps. This results in a relatively high off-line parasitic load.

Based on this analysis, the trough spreadsheet performance model appears to be an appropriate tool for modeling the performance of parabolic trough power plants. The input parameters can be changed to reflect design changes in plant design. Although the model includes thermal storage, this module has not been validated against a real plant; however, the module appears to be functioning correctly based on the output from the model.

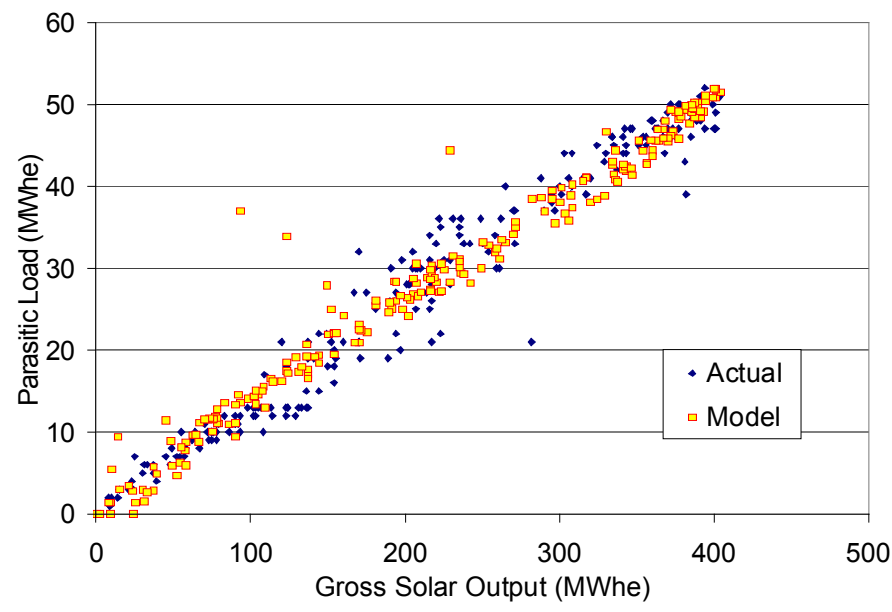

Figure 2 Daily modeled and actual on-line parasitic loads
Table 2 Comparison of Actual versus Modeled Parasitic Electric Loads (SEGS VI 1999)

\begin{tabular}{|c|c|c|c|c|c|c|c|c|}
\hline & \multicolumn{4}{|c|}{$\underline{\text { On-Line Parasitic Loads }}$} & \multicolumn{4}{|c|}{ Off-Line Parasitic Loads } \\
\hline & $\begin{array}{l}\text { No. of } \\
\text { Days }\end{array}$ & $\begin{array}{l}\text { Actual } \\
\text { MWh }\end{array}$ & $\begin{array}{c}\text { Model } \\
\text { MWh }\end{array}$ & & & $\begin{array}{l}\text { Actual } \\
\text { MWh }\end{array}$ & $\begin{array}{c}\text { Model } \\
\text { MWh }\end{array}$ & $\begin{array}{r}\text { Model / } \\
\text { Actual }\end{array}$ \\
\hline Jan & 0 & 0 & 0 & & 0 & 0 & 0 & \\
\hline Feb & 0 & 0 & 0 & & 0 & 0 & 0 & \\
\hline Mar & 31 & 720 & 632 & $87.8 \%$ & 31 & 264 & 252 & $95.5 \%$ \\
\hline Apr & 30 & 789 & 795 & $100.8 \%$ & 30 & 247 & 236 & $95.4 \%$ \\
\hline May & 30 & 1,168 & 1,117 & $95.6 \%$ & 30 & 208 & 200 & $96.1 \%$ \\
\hline Jun & 18 & 866 & 872 & $100.7 \%$ & 18 & 109 & 104 & $95.1 \%$ \\
\hline Jul & 18 & 781 & 816 & $104.4 \%$ & 18 & 115 & 112 & $97.5 \%$ \\
\hline Aug & 9 & 381 & 385 & $100.9 \%$ & 9 & 57 & 58 & $101.6 \%$ \\
\hline Sep & 9 & 304 & 299 & $98.4 \%$ & 9 & 61 & 61 & $100.2 \%$ \\
\hline Oct & 31 & 666 & 747 & $112.2 \%$ & 31 & 225 & 229 & $101.9 \%$ \\
\hline Nov & 30 & 289 & 350 & $121.2 \%$ & 30 & 266 & 264 & $99.4 \%$ \\
\hline Dec & 20 & 182 & 195 & $107.2 \%$ & 20 & 187 & 174 & $93.2 \%$ \\
\hline Total & 226 & 6,146 & 6,207 & $101.0 \%$ & 226 & 1,739 & 1,690 & $97.2 \%$ \\
\hline
\end{tabular}

\section{Capital Cost Model}

NREL has developed a detailed cost model for parabolic trough solar power plants. The model is a based largely on input from FSI, which supplied the mirrors for all of the Luz plants, and has been actively working to promote parabolic trough plants since Luz's bankruptcy in 1991 [2]. FSI has developed a detailed cost model based initially on the cost data from the Luz SEGS X project and later updated with more recent vendor quotes [7]. FSI provided cost data to NREL as part of its participation in the 1998 Parabolic Trough Road-Mapping Workshop [8] and updated the solar field costs under contract to 
NREL in 1999 [9]. The FSI cost model is very detailed and uses reference quotes for each cost element. When the quote is for a specific equipment capacity, the model uses scaling factors to adjust the costs for sizes other than the reference cases. The scaling equation takes the general form:

$$
\text { Cost } 2=(\mathrm{C} 2 / \mathrm{C} 1)^{0.7} \times \text { Cost } 1
$$

where:

Cost1 is the reference cost for a piece of equipment of capacity $\mathrm{C} 1$

Cost 2 is the predicted cost of the equipment at the desired capacity $\mathrm{C} 2$.

The exponent varies for each cost element and is calculated from two reference quotes; however, 0.7 is used for common equipment when only one quote is available.

The cost data provided to NREL is a summarized version. All components that make up the collector structure, for example, are grouped into a single cost element. The NREL cost model uses the same scaling factor approach to adjust costs on the grouped expenses. The NREL cost model generally reproduces the FSI costs within a few percentage points. The cost data has been modified in a few places to better reflect the baseline parabolic trough system that would be built. Specifically, the collector model has been enhanced to account for different collector designs. The thermal storage costs are based on the Nexant thermal storage cost model [10] and adjusted for variations in thermal storage configuration as appropriate [11]. All variations from the Flabeg cost assumptions are detailed in the appropriate section below.

Land: A parabolic trough field uses approximately one hectare per $3,000 \mathrm{~m}^{2}$ of collector area, or a coverage of factor of about $0.3 \mathrm{~m}^{2}$ of collector for every $1.0 \mathrm{~m}^{2}$ of land area.

Site Works and Infrastructure: The site works and infrastructure includes general land preparation, roads, fences, and site infrastructures, such as firewater system, warehouse, and control building. The cost model assumptions are based on the FSI input. This category scales based on the size of the solar field.

Solar Field: The solar-field cost estimates are based on an updated cost assessment produced by FSI [9]. The cost estimate is based on the LS-3 collector design. Several adjustments are made to the collector cost to account for a specific collector design used:

- The number of receiver tubes, flex hoses, drives, sensors, and local controllers are adjusted per unit area of collector.

- The drive costs are adjusted to account for the collector size.

- The mirror, steel structure, pylons, header piping, and civil work costs are assumed to be the same on a per-squaremeter basis for different collectors.

Heat Transfer Fluid (HTF) System: The HTF system includes the HTF pumps, solar heat exchangers, HTF expansion vessel, piping, valves, and instrumentation. HTF system costs scale based on the power-plant size, except for the HTF pumps, which scale based on solar-field size. The HTF costs are based on the FSI roadmap data. The later data was only appropriate for an ISCCS-type plant.

Thermal Energy Storage (TES): The thermal storage costs are based on the detailed design study performed by Nexant for a two-tank, molten-salt storage system [10]. Thermal storage tanks and costs are based on detailed data from Solar Two and Solar Tres. The heat exchanger costs are based on manufacturer quotes. Storage costs were broken into mechanical equipment (pumps and heat exchangers), tanks, nitrate salt, piping, instrumentation and electrical, and civil and structural. The mechanical equipment and piping, instrumentation, and electrical costs were scaled by power-plant size. The tank, salt, and civil costs were scaled by storage volume. All storage costs assume a scaling factor of 1.0, so a storage system twice as big costs twice as much. Thermal storage tank and salt costs are consistent between the trough and tower designs. The trough thermal storage system must be approximately three times as big as the tower storage system (both in tank size and volume of salt required) to store as much energy because of the much lower temperature difference between the fluid in the hot and cold tanks in the trough plant.

Power Cycle: The power cycle includes the steam turbine and generator and all condensate and steam cycle equipment including pumps, heat exchangers, piping, valves, instrumentation, and controls. The FSI studies [2] have the most recent Rankine steam-cycle cost data for the systems used in trough designs.

Balance of Plant: The BOP includes other power plant systems, such as cooling towers, water treatment and storage, electrical, and control systems.

Contingencies: Contingencies of $10 \%$ are included for all costs, except the solar field (5\%), structures and improvements $(20 \%)$, and thermal storage. The cost of the solar field is very well understood at this point. The larger contingency for structures and improvements is included to account for potential differences in site preparation. Nexant included cost contingencies separately in the thermal storage.

Indirect Costs: Indirect costs include services, project costs, and management reserve. The indirect cost assumptions were based on input from Nexant. Service costs include project management, project engineering, and construction management services. Project costs include permits and licenses, utility connections, and telecommunication links. No interest during construction is included; this is accounted for in the financial model.

\section{O\&M COST MODEL}

The O\&M cost model is an expansion of the work presented in the KJCOC O\&M cost reduction study [12]. The model builds on the KJCOC methodology for O\&M of largescale parabolic trough power plants. The O\&M costs are broken into categories of labor, spare parts, and equipment and into 
administration, operations, power block maintenance, and solar field maintenance. The overall staffing levels and costs are based on assumptions provided by KJCOC. Solar field spare parts requirements are based on actual maintenance experience at KJCOC. The trough receiver replacement rate is the key solar field spare part, and appropriate assumptions can be adjusted for specific case. The power plant spare part requirements are assumed to be $0.4 \%$ of the system capital cost on an annual basis. This is partially an accrual for major plant maintenance overhauls to be conducted every 5 to 10 years. The model also included service contracts, water costs, and miscellaneous administrative costs. The model predicts O\&M costs similar to those at the KJCOC facilities.

\section{FINANCIAL MODEL}

The model assumes a financial structure of an independent power producer (IPP) project. This is the type of structure used in the SEGS projects and is the most likely project structure for future trough power projects. Kistner [13] provides a good overview of IPP project financial methodology. The NREL financial model is a 30-year cash-flow model adapted from the Wiser and Kahn [14] wind model for IPP projects. The model has been modified to allow 30-year project life and account for solar specific tax incentives. The model calculates the levelized cost of energy (LCOE) and can be used to optimize the IPP financial structure to minimize the real LCOE.

\section{ANALYSIS EXAMPLE}

The primary advantage of the NREL trough simulation model is that it integrates the capital cost, O\&M cost, performance and financial constraints into a single model. This allows detailed design or project optimizations to be carried out where all interactions between cost and performance can be accounted. The NREL model has proven to be a valuable tool for the CSP trough program R\&D analysis and has been used extensively over the past few years to guide R\&D program direction. This section highlights one recent study that used the NREL model.

\section{Thermal Energy Storage Optimization}

In a recent study by Kearney [15], the NREL trough model was used to optimize the design of a two-tank indirect moltensalt thermal energy storage system. The analysis determined the optimum solar field size and heat exchanger areas for various thermal energy storage capacities. A 50-MWe SEGS plant was simulated with $2,4,6,9$, and 12 hours of TES. For each storage size, system designs were developed for heat exchangers with $\log$ mean temperature differences (LMTD) of 2 to $15^{\circ} \mathrm{C}$. The analysis identified the heat exchanger LMTD design and solar field size that provided the lowest cost of energy for each size of TES. In general, the lowest investment cost thermal storage system does not offer the lowest cost of energy because of the affect of the TES system on plant efficiency.
TES Design Assumptions: Nexant [16] developed the TES system costs, solar field return temperatures, and power cycle efficiencies for the analysis. Nexant also provided TES thermal loss assumptions in the study. Table 3 provides general design data for the 6-hour storage system.

Table 3 A 6-Hour TES system design for 50-MWe trough plant

\begin{tabular}{lcc}
\hline & Cold Tank & Hot Tank \\
\hline Number of tanks & 1 & 1 \\
Height, m & 14.0 & 14.0 \\
Diameter, m & 34.2 & 34.7 \\
Floor, wall, and roof area, $\mathrm{m}^{2}$ & $3,335.9$ & $3,422.1$ \\
Inventory temperature, C & 292 & 389 \\
Mean insulation temperature, C & 159 & 207 \\
Thermal conductivity, $\mathrm{J} / \mathrm{sec}-\mathrm{m}-{ }^{\circ} \mathrm{C}$ & 0.0664 & 0.0716 \\
Insulation thickness, $\mathrm{m}$ & 0.28 & 0.36 \\
Tank heat loss, $\mathrm{kWt}$ & 210 & 246 \\
\hline
\end{tabular}

Parabolic Trough Plant Assumptions: The parabolic trough plant design is based on assumptions for a near-term plant using LS-2 solar collectors and Solel UVAC receivers. General trough plant assumptions are shown in Table 4 for a sample plant with 6 hours of TES and a heat exchanger LMTD of $7^{\circ} \mathrm{C}$. Note that the power cycle efficiency is different depending on whether the thermal input comes from the solar field or the TES system.

Capital and O\&M Cost Assumptions: The capital cost and O\&M costs as estimated by the NREL cost models for the 6hour storage case are shown in Tables 5 and 6.

TES Dispatch Strategy: The plant was assumed to operate to dispatch energy to a summer afternoon peak period and a winter evening peak period. The model uses a fairly simple dispatching strategy, which was not fully optimized for each run. An improved dispatch strategy would probably result in reduced dumping of energy and improve the cost of energy for some of the plant configurations.

Power Plant Operations: During normal operation at the SEGS plants, the solar fields and the power plant are operated to maximize net solar electric output. The solar field temperature is dropped in the winter because the power plant is operated at a lower load and the higher temperatures are not required to maintain the minimum required steam superheat. In the summer, steam cycle feedwater heaters are often bypassed to reduce the amount of solar field dumping. The turbine cycle is allowed to operate at about $115 \%$ of design output when excess solar energy is available. In the TES analysis, we limited the turbine output to $100 \%$ of design. We will consider a second case later where the turbine cycle is allowed to go to $115 \%$ of design point. 
Table 4 Design Assumptions for 50-MWe Trough Plant with 6 hours TES

\begin{tabular}{|c|c|c|}
\hline \multicolumn{3}{|c|}{ Site: Kramer Junction, California, USA } \\
\hline Data Source & \multicolumn{2}{|c|}{ KJCOC 1999 Data } \\
\hline Longitude & 117.5 & degrees $\mathrm{W}$ \\
\hline Latitude & 35.15 & degrees $\mathrm{N}$ \\
\hline DNI & 8.054 & $\mathrm{kWh} / \mathrm{m}^{2} /$ day \\
\hline \multicolumn{3}{|l|}{ Collector Field } \\
\hline Collector Type & LS-2+ & \\
\hline Optical Efficiency & 0.763 & \\
\hline Mirror Cleanliness Factor & 0.95 & \\
\hline Solar Field Availability & 0.99 & \\
\hline Collector Area & 458,720 & $\mathrm{~m}^{2}$ \\
\hline Receiver Heat Losses & 77 & $\mathrm{~W} / \mathrm{m}^{2}$ \\
\hline Piping Heat Losses & 10 & $\mathrm{~W} / \mathrm{m}^{2}$ \\
\hline Solar Field Cost & 242 & $\$ / m^{2}$ \\
\hline \multicolumn{3}{|l|}{ Thermal Storage } \\
\hline Full Load Equivalent Hours & 6 & hrs \\
\hline Max Energy In Storage & 874 & $\mathrm{MWh}_{\mathrm{t}}$ \\
\hline Thermal Losses & 0.46 & $\mathrm{MW}_{\mathrm{t}}$ \\
\hline Log Mean Temp Difference & 7 & ${ }^{\circ} \mathrm{C}$ \\
\hline TES Cost & 31.4 & $\$ / \mathrm{kWh}_{\mathrm{t}}$ \\
\hline \multicolumn{3}{|l|}{ Power Block } \\
\hline Net/Gross Output & $50 / 55$ & $\mathrm{MW}_{\mathrm{e}}$ \\
\hline $\begin{array}{l}\text { Gross Cycle Efficiency (thermal } \\
\text { from Solar Field /TES) }\end{array}$ & $0.377 / 0.371$ & \\
\hline Max Output & 1.00 & $\%$ of design \\
\hline Min Output & 0.15 & $\%$ of design \\
\hline
\end{tabular}

Table 5 Capital Cost Assumptions (50 MWe, 6 hrs TES)

\begin{tabular}{llc}
\hline Capital Cost & $(\mathrm{k} \$)$ \\
1 & Structures and Improvements & 4,805 \\
2 & Collector System & 110,906 \\
3 & Thermal Storage System & 27,455 \\
4 & Steam Gen or HX System & 6,798 \\
5 & Auxiliary Heater/Boiler & 0 \\
6 & Turbine Generator & 24,860 \\
7 & Balance of Plant & 14,454 \\
& Total Direct Costs & $\mathbf{1 8 9 , 2 7 9}$ \\
Indirect Costs & \\
Engineering, Construction, & \\
and Project Management & 13,817 \\
Land Cost & $\mathbf{7 6 4}$ \\
Total Indirect & $\mathbf{1 4 , 5 8 1}$ \\
Total Cost & $\mathbf{2 0 3 , 8 6 0}$ \\
\hline
\end{tabular}

Table 6 O\&M Cost Assumptions (50 MWe, 6 hrs TES)

\begin{tabular}{lccccc}
\hline & & Labor & Parts Equipment & Total \\
O\&M Cost & Staff & $\mathbf{( k \$ )}$ & $\mathbf{( k \$ )}$ & $\mathbf{( k \$ )}$ & $\mathbf{( k \$ )}$ \\
\hline Admin & 7 & 440 & 253 & 0 & 693 \\
Operations & 13 & 746 & 249 & 0 & 994 \\
PB Maintenance & 8 & 527 & 313 & 0 & 841 \\
SF Maintenance & 7 & 391 & 600 & 90 & 1,081 \\
\hline Total & $\mathbf{3 4}$ & $\mathbf{2 , 1 0 4}$ & $\mathbf{1 , 4 1 6}$ & $\mathbf{9 0}$ & $\mathbf{3 , 6 0 9}$ \\
\hline
\end{tabular}

\section{Optimization}

The performance model was run with Kramer Junction 1999 insolation data to evaluate TES designs for the 50-MWe trough plant. A parametric analysis was carried out to determine the optimum solar field size for each TES capacity and heat exchanger configuration (LMTD). Figure 2 shows the solar field size optimization for a system with 6 hours of storage.

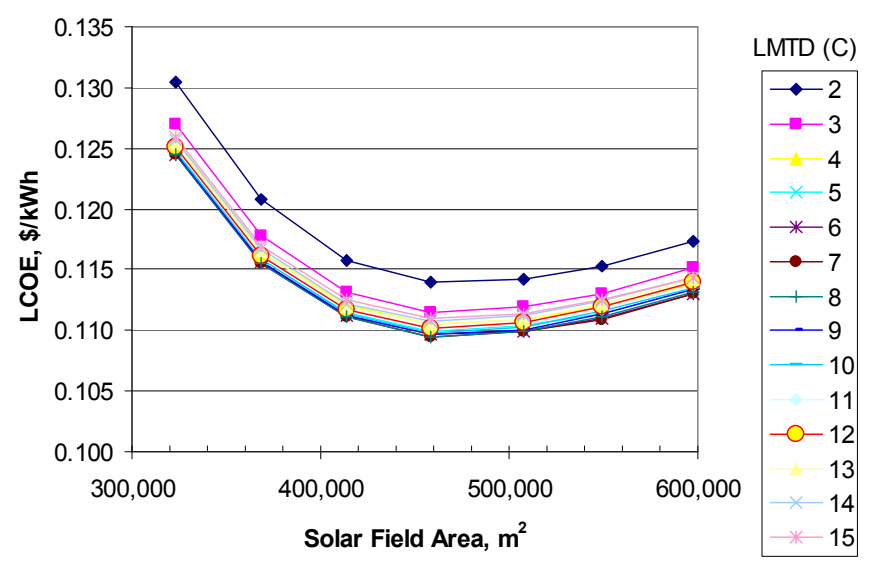

Figure 2 Solar field size optimization for 6 hours of TES

The lowest cost of energy for a plant with 6 hours of TES occurs with a solar field of approximately $460,000 \mathrm{~m}^{2}$ (Figure 2). Using the optimum solar field size for each case, Figure 3 shows the levelized energy cost for each heat exchanger/TES design for different storage capacities. The optimum TES heat exchanger LMTD is highlighted for each storage capacity. Adding thermal storage clearly reduces the LCOE. Larger TES capacities are optimized with lower LMTDs.

To help in understanding these results, it can be instructive to look at more detailed design and performance results from the model. Table 7 shows a summary of the optimized designs for the no-storage case and the 6-hour thermal storage case. The plant with storage has a larger solar field. The optimum heat exchanger LMTD is $7^{\circ} \mathrm{C}$. The capital cost of the plant with 6 hours of TES is $54 \%$ higher, but it produces $62 \%$ more energy and has a lower O\&M cost per kilowatt-hour generated. The resulting cost of energy is $10 \%$ lower with 6 hours of storage. 


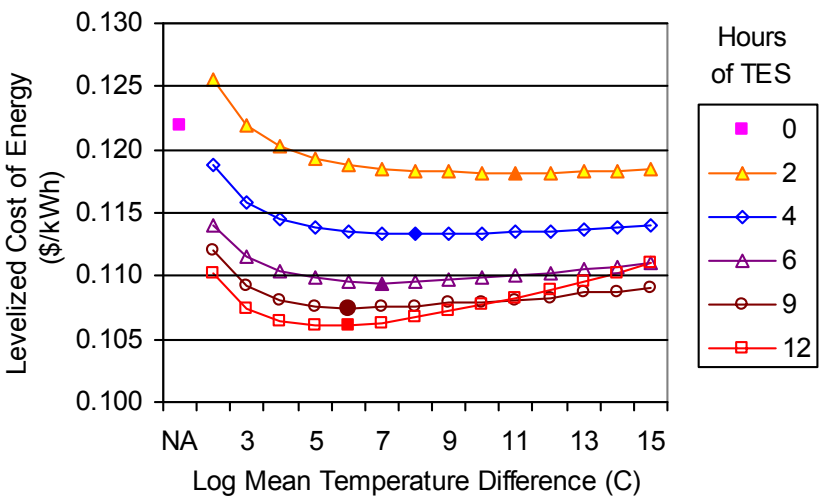

Figure 3 TES Heat Exchanger Optimization for 50-MWe Trough Plant

Table 7 Model Performance Results for 50-MWe trough plants, 0 and 6 hours TES

\begin{tabular}{lcc}
\hline \multicolumn{1}{c}{ TES Size } & $\mathbf{0 ~ h r s}$ & $\mathbf{6 ~ h r s}$ \\
& TES & TES \\
\hline Solar Field Size, $\mathrm{m}^{2}$ & 300,800 & 458,720 \\
Heat Exchanger Size (LMTD), ${ }^{\circ} \mathrm{C}$ & na & $7^{\circ}$ \\
Capacity Factor & $25.0 \%$ & $40.6 \%$ \\
Capital Cost, k\$ & 132,619 & 203,860 \\
Operation \& Maintenance Cost, \$/kWh & 0.0283 & 0.0203 \\
\hline LCOE, \$/kWh & 0.1223 & 0.1095 \\
\hline Annual Performance Calculation & & \\
Direct Normal Solar Radiation & 1.000 & 1.000 \\
Incidence Angle (1-axis tracking) & 0.873 & 0.873 \\
Solar Field Availability & 0.990 & 0.990 \\
Solar Field Optical Efficiency & 0.694 & 0.694 \\
Receiver Thermal Losses (24 hr) & 0.795 & 0.794 \\
Piping Thermal Losses (24 hr) & 0.966 & 0.966 \\
No Operation, Low Insolation & 0.998 & 0.998 \\
TES Full & NA & 0.944 \\
TES Thermal Losses & NA & 0.993 \\
Turbine Start-up & 0.961 & 0.983 \\
Excess to PB/TES & 0.911 & 0.999 \\
Below turbine minimum & 0.991 & 1.000 \\
Power plant steam cycle efficiency & 0.379 & 0.375 \\
Parasitics & 0.871 & 0.884 \\
Plant-wide Availability & 0.940 & 0.940 \\
Annual Solar to Electric Efficiency & $\mathbf{1 2 . 4 \%}$ & $\mathbf{1 3 . 2 \%}$ \\
\hline & &
\end{tabular}

Table 7 also shows the annual efficiency for the plant with and without thermal storage and includes a detailed breakdown of the factors that affect the annual efficiency for each case. These factors, although shown as annualized numbers, are calculated on an hourly basis within the performance model. The annual efficiency is based on the total annual direct normal beam radiation from the sun. The incidence angle factor accounts for losses caused by the single axis tracking nature of parabolic trough collectors. For trough plants with a horizontal north-south axis of rotation, at 35 degrees north latitude approximately $13 \%$ of the direct normal radiation is lost on an annual basis because of incidence angle effects. Solar field availability accounts for the percent of the solar field tracking when the field should be operating. Solar field availabilities above $99 \%$ are common at the SEGS plants. The solar field optical efficiency factor accounts for gaps in the mirrors, solar weighted mirror reflectivity and soiling, concentrator focal accuracy, collector tracking accuracy, receiver envelope glass transmittance and soiling, blockage by the bellows and other obstructions, and the absorption of the receiver black coating.

The annual optical efficiency also accounts for end losses resulting from light that reflects off the end of the collector, row-to-row shadowing shortly after sunrise and shortly before sunset, and incidence angle effects of the reflector and receiver optical properties when the sun is not directly normal to the collector aperture. Receiver thermal losses account for the thermal losses back to the environment from the receiver. Thermal storage increases receiver thermal losses slightly because of the higher HTF return temperature to the solar field. The thermal losses from piping are similar between the two cases. The system with thermal storage has two types of losses: losses when the storage system is full (and the power plant cannot accept the energy because it already at maximum load) and thermal losses from the storage system.

However, turbine start-up becomes a smaller fraction of total energy use, because the turbine is operated for more hours with fewer starts. The addition of thermal storage means there are fewer hours when energy must be dumped because the power block cannot accept all of the thermal energy coming from the solar field. TES also allows energy to be stored during periods of low solar radiation when insufficient energy is available to operate the power plant. The power plant steam cycle efficiency is slightly lower in the TES case because of the lower steam temperatures when operating from storage. Electric parasitics are slightly lower from the plant with thermal storage because of the higher annual generation and lower percentage of off-line parasitic electric consumption. The plantwide availability factor accounts for plant planned and forced outages or deratings. This is assumed to be the same for both systems. Thermal storage could impact plant availability because the plant will be operating more hours during the year and leaving less downtime opportunities for doing maintenance. However, thermal storage also provides a buffer between the solar field and power plant and could reduce availability losses due to short-term power plant outages or deratings. Solar field energy 
that might otherwise be lost can be stored for later generation. Multiplying out all these factors gives the annual efficiency for each system. The annual efficiency is higher for the plant with thermal storage.

These two cases that are being compared are the optimum designs for each. This means that the solar fields have been sized to provide the minimum cost of energy for that plant design. Clearly, the solar field size could be reduced in the nostorage case to reduce the losses of excess energy to the power plant. This might result in a higher annual solar-to-electric efficiency; however, it would also result in a higher cost of electricity. It was previously noted that the turbine was limited to $100 \%$ of design gross electric output in this analysis. In actual operational practice, the operators of the SEGS plants routinely operate the plants up to $115 \%$ of design output when sufficient solar input exists. Figure 4 highlights the effect of allowing the turbine to operate up to $115 \%$ of design. The plant designs for the $115 \%$ curve are not the same as the $100 \%$ curve. The solar field sizes were re-optimized and are larger in the $115 \%$ cases. Allowing the plant to operate at higher output is comparable to reducing the capital cost of the power plant. The impact is largest for the case without thermal storage, because the solar field can be increased the most. In this case, the benefit of adding thermal storage is reduced if the plant is allowed to operate above design output.

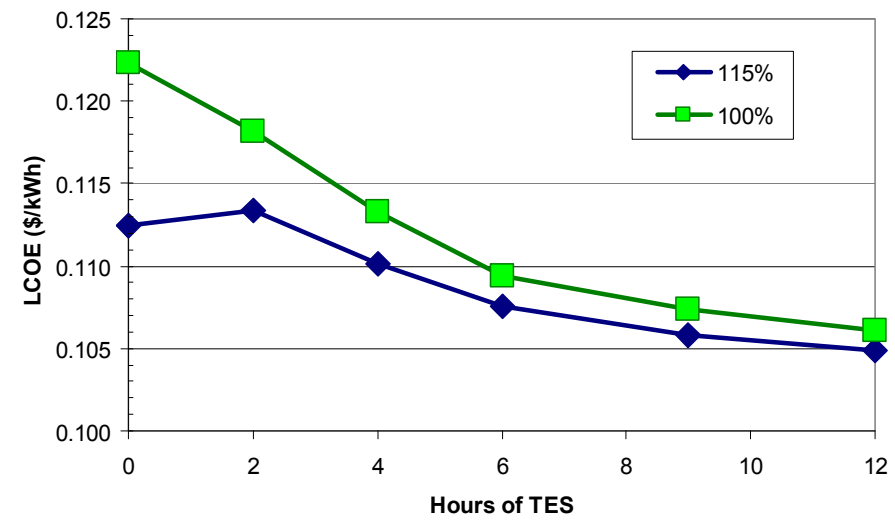

Figure 4 Impact of Turbine Maximum Operational Load

This thermal storage design optimization study provides a good example of why the NREL model is valuable. The optimization includes complex interactions in components that affect the capital and O\&M cost and the system performance. The size of the TES heat exchanger affects the TES system cost, the solar field return temperature, and the power cycle supply temperature. The TES cost is impacted by the heat exchanger cost, but also the resulting temperature difference between the hot and cold tank, which affects the physical volume, required for storing a fixed amount of thermal energy. The solar field return temperature impacts the resulting solar field heat losses and HTF pumping parasitics. The power cycle supply temperature affects the power cycle efficiency and resulting electric output. Even operating constraints, such allowing the turbine to operate above rated output, can significantly impact the optimum design.

\section{CONCLUSIONS}

NREL has developed a parabolic trough model that integrates system capital and O\&M cost, plant performance, and economic analysis. This provides an important tool that has been used to assess the value of R\&D efforts, help optimize plant designs, and support commercial project development efforts. The annual performance calculated by the model has been validated against actual operating data from the one of the existing SEGS plants.

\section{ACKNOWLEDGMENTS}

The author would like to thank KJC Operating Company for providing plant performance and O\&M data, and the U.S. Department of Energy's Concentrating Solar Power Program for support of this work.

\section{NOMENCLATURE}

$\begin{array}{ll}\text { CSP } & \text { concentrating solar power } \\ \text { DLR } & \text { Deutsches Zentrum fur Luft-und Raumfahrt } \\ & \text { e.V } \\ \text { DOE } & \text { Department of Energy } \\ \text { DNI } & \text { direct normal insolation } \\ \text { FSI } & \text { Flabeg Solar International } \\ \text { HCE } & \text { heat collection element } \\ \text { HTF } & \text { heat transfer fluid } \\ \text { IPP } & \text { independent power producer } \\ \text { ISCCS } & \text { integrated solar combined cycle system } \\ \text { KJCOC } & \text { KJC Operating Company } \\ \text { LCOE } & \text { levelized cost of energy } \\ \text { LMTD } & \text { log mean temperature difference } \\ \text { LS-2 } & \text { Luz second-generation trough collector } \\ \text { LS-3 } & \text { Luz third-generation trough collector } \\ \text { NREL } & \text { National Renewable Energy Laboratory } \\ \text { O\&M } & \text { operation and maintenance } \\ \text { PB } & \text { power block } \\ \text { R\&D } & \text { research and development } \\ \text { SEGS } & \text { solar electric generating system } \\ \text { SF } & \text { solar field } \\ \text { SNL } & \text { Sandia National Laboratory } \\ \text { TES } & \text { thermal energy storage } \\ \text { TMY } & \text { typical meteorological year } \\ & \end{array}$

\section{REFERENCES}

[1] Luz International Limited (LIL), 1990, "Solar Electric Generating System IX (SEGS IX) Project Description," LIL Documentation, Los Angeles, CA.

[2] Pilkington Solar International GmbH, 1996, "Status Report on Solar Thermal Power Plants," ISBN 39804901-0-6, Köln, Germany. 
[3] Nelson, R., and Cable, R., 1999, "The KJC Plant Performance Model - An Improved SEGS Plant Simulation," Proceedings of the ASES 1999, Annual Conference.

[4] Quaschning, V., Kistner, R., Ortmanns, W., Geyer, and M., 2001, "Greenius - A new Simulation Environment for Technical and Economical Analysis of Renewable Independent Power Projects," Proceedings of ASME International Solar Energy Conference Solar Forum 2001. Washington DC, 22-25 April 2001.

[5] Jones, S., Pitz-Paal, R., Schwarzboezl, P., Blair, N., and Cable, R., 2001, "TRNSYS Modeling Of The SEGS VI Parabolic Trough Solar Electric Generating System," Proceedings of ASME International Solar Energy Conference Solar Forum 2001. Washington DC, 22-25 April 2001.

[6] Stine, W. and Harrigan, R., 1985, Solar Energy Fundamentals and Design with Computer Applications, Wiley Interscience, New York.

[7] Flachglas Solartechnik GmbH, 1994, "Assessment of Solar Thermal Trough Power Plant Technology and its Transferability to the Mediterranean Region," Final Report, prepared for the European Commission Directorate General I-External Economic Relations, Köln, Germany.

[8] Price, H., and Kearney, D., 1999, "Parabolic-Trough Technology Roadmap: A Pathway for Sustained Commercial Development and Deployment of ParabolicTrough Technology,” NREL/TP-550-24748, National Renewable Energy Laboratory, Golden, CO.

[9] Pilkington Solar International GmbH, 1999, "Solar Steam System Investment Cost," Prepared for NREL by Pilkington, Köln, Germany.

[10] Nexant, 2000, "Thermal Storage Oil-to-Salt Heat Exchanger Design and Safety Analysis," Report to NREL, San Francisco, CA., November 30, 2000.

[11] Kearney \& Associates, 2001, "Engineering Evaluation of a Molten Salt HTF in a Parabolic Trough Solar Field," Final Report, NREL Contract No. NAA_1-30441-04, Vashon, WA.

[12] Cohen, G., Kearney, D., and Kolb, G., 1999, "Final Report on the Operation and Maintenance Improvement Program for CSP Plants," Report No. SAND99-1290, Sandia National Laboratory, Albuquerque, NM.

[13] Kistner, R. and Price, H. 1999, "Financing Solar Thermal Power Plants," Proceedings of the ASME Renewable and Advanced Energy Systems for the 21st Century Conference, April 11-14, 1999, Maui, Hawaii.

[14] Wiser, R., and Kahn, E., 1996, "Alternative Windpower Ownership Structures: Financing Terms and Project Costs," LBNL-38921, Lawrence Berkeley National Laboratory, Berkeley, CA.

[15] Kearney, D, Kelly, B., and Price, H., 2002, "Thermal Storage Commercial Plant Design Study for a 2-Tank
Indirect Molten Salt System," Final Report, NREL Contract No. AAA-2-32432-01, October 25, 2002.

[16] Kelly, B., 2002, "Rankine Cycle, Steam Generator, and Two-Tank Thermal Storage Parametric Studies," Prepared for NREL, Nexant, San Francisco, CA, September 2002. 


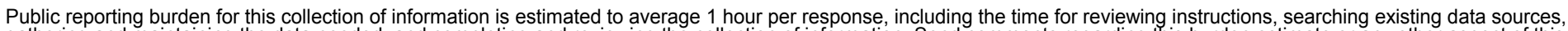

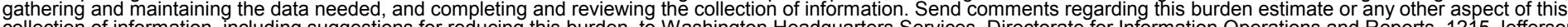
Davis Highway, Suite 1204, Arlington, VA 22202-4302, and to the Office of Management and Budget, Paperwork Reduction Project (0704-0188), Washington, DC 20503.
1. AGENCY USE ONLY (Leave blank)
2. REPORT DATE January 2003

\section{REPORT TYPE AND DATES COVERED Conference Paper}

4. TITLE AND SUBTITLE

A Parabolic Trough Solar Power Plant Simulation Model: Preprint

5. FUNDING NUMBERS

6. $\operatorname{AUTHOR}(\mathrm{S})$

H. Price

7. PERFORMING ORGANIZATION NAME(S) AND ADDRESS(ES)

National Renewable Energy Laboratory

1617 Cole Blvd.

CP03.2000

Golden, CO 80401-3393

9. SPONSORING/MONITORING AGENCY NAME(S) AND ADDRESS(ES)

10. SPONSORING/MONITORING AGENCY REPORT NUMBER

11. SUPPLEMENTARY NOTES

12a. DISTRIBUTION/AVAILABILITY STATEMENT

National Technical Information Service

12b. DISTRIBUTION CODE

U.S. Department of Commerce

5285 Port Royal Road

Springfield, VA 22161

13. ABSTRACT (Maximum 200 words) As interest for clean renewable electric power technologies grows, a number of parabolic trough power plants of various configurations are being considered for deployment around the globe. It is essential that plant designs be optimized for each specific application. The optimum design must consider the capital cost, operations and maintenance cost, annual generation, financial requirements, and time-of-use value of the power generated. Developers require the tools for evaluating tradeoffs between these various project elements. This paper provides an overview of a computer model that is being used by scientists and developers to evaluate the tradeoff between cost, performance, and economic parameters for parabolic trough solar power plant technologies. An example is included that shows how this model has been used for a thermal storage design optimization.

14. SUBJECT TERMS parabolic trough; solar power plant; clean renewable electric power; simulation model

15. NUMBER OF PAGES

17. SECURITY CLASSIFICATION OF REPORT Unclassified

\author{
18. SECURITY CLASSIFICATION \\ OF THIS PAGE \\ Unclassified
}

19. SECURITY CLASSIFICATION OF ABSTRACT Unclassified
16. PRICE CODE

20. LIMITATION OF ABSTRACT

UL 